\section{SCIENCE IN ADULT EDUCATION}

\author{
By D. M. H. CLIFFORD \\ Board of Extra-Mural Studies, University of Cambridge
}

$\mathrm{D}^{\mathrm{c}}$ URING 1946, full-time appointments of tutors to give extra-mural instruction in the natural sciences were made both by the University of Birmingham and by the University of Cambridge. The inclusion of natural scientists in the staffs of extramural departments is a development which reflects the increasing recognition of the importance of, and the growing demand for, the teaching of science to adults.

The Education Act of 1944 has charged local authorities with the duty of securing for their areas the provision of adequate facilities for further education. But in this undertaking they are required to consult with the university extra-mural departments and with the voluntary bodies, such as the Workers' Educational Association, which have built up traditions and developed practice in this field over very many years. The cost of lecture courses provided by these bodies is met in part by direct grants from the Ministry of Education amounting to not less than three-quarters of the lecturers' fees, subject to the classes conforming to regulations determined by the Minister. For the year 1944-45 approximately $£ 105,000$ was thus disbursed by the Ministry. Tuition is given in courses which vary in duration and in the level of instruction. Terminal and university extension courses usually extend to twelve lectures, while sessional classes normally include twenty-four lectures. Tutorial classes extend over three successive winter sessions, each session comprising twenty-four weekly meetings. In this provision for further education the representation of scientific subjects has been, and still is, very slight. During 1944-45 natural science courses in England, Wales and Scotland arranged by the Workers' Educational Association, either on its own or in co-operation with universities, amounted to not more than 4.5 per cent of the total number of courses in all subjects. This figure excludes courses in psychology $(6 \cdot 9$ per cent of total) and in anthropology $(0 \cdot 2$ per cent). These are customarily classed with the social sciences. In a large number of cases the approach to psychology is philosophical rather than experimental. The accompanying table records the provision of science courses during the last four sessions by the Board of Extra-Mural Studies of the University of Cambridge, having regard to the two sides of its work. Extension lectures are provided through local centres committees: tutorial and sessional classes are normally provided by joint action with the Workers' Educational Association.

Board of Extra-Murat Studies, University of Cambridge. FREQUENCY OF COURSES IN NATURAL SCIENCES, 1942-46

\begin{tabular}{|c|c|c|c|c|c|c|}
\hline \multirow{3}{*}{ Session } & \multicolumn{3}{|c|}{$\begin{array}{l}\text { University extension } \\
\text { courses }\end{array}$} & \multicolumn{3}{|c|}{$\begin{array}{c}\text { Tutorial and sessional } \\
\text { classes }\end{array}$} \\
\hline & \multirow{2}{*}{$\begin{array}{c}\text { Total } \\
\text { courses } \\
\text { in all } \\
\text { subjects }\end{array}$} & \multicolumn{2}{|c|}{ Courses in science* } & \multirow{2}{*}{$\begin{array}{c}\text { Total } \\
\text { courses } \\
\text { in all } \\
\text { subjects }\end{array}$} & \multicolumn{2}{|c|}{ Courses in science* } \\
\hline & & Number & $\begin{array}{l}\text { Per cent } \\
\text { of total }\end{array}$ & & Number & $\begin{array}{l}\text { Per cent } \\
\text { of total }\end{array}$ \\
\hline $\begin{array}{l}1942-43 \\
1943-44 \\
1944-45 \\
1945-46\end{array}$ & $\begin{array}{l}74 \\
81 \\
93 \\
69\end{array}$ & $\begin{array}{l}1 \\
2 \\
1 \\
1\end{array}$ & $\begin{array}{l}1 \cdot 4 \\
2 \cdot 5 \\
1 \cdot 1 \\
1 \cdot 5\end{array}$ & $\begin{array}{l}28 \\
30 \\
63 \\
73\end{array}$ & $\begin{array}{r}3 \\
1 \\
5 \\
12\end{array}$ & $\begin{array}{r}10 \cdot 7 \\
3 \cdot 3 \\
7 \cdot 9 \\
16 \cdot 4\end{array}$ \\
\hline
\end{tabular}

* Chiefly biology or the social relations of science.
In the latter connexion it will be observed that there has, during the last four years, been a marked expansion in the number, and, to a less extent, in the proportion, of courses in science. This growth can in part be correlated with the availability of certain tutors, chiefly biologists, and with a planned endeavour to discover reasons for the apparent lack of interest in science among adult students, an occurrence which did not correspond well with the known demand for popular books on scientific subjects. Certain aspects of that problem are discussed below.

To some extent, unfamiliarity with science on the part of organisers and administrators in adult education has put science courses at a disadvantage when, in company with more familiar alternatives such as literature, history and social studies, they have been set before potential student groups for choice to be made of a subject of study for the ensuing year. Secondly, there has been an insufficiency of scientific workers offering themselves as tutors, partly on account of indifference to the claims of such work, but also on account of an unawareness of its existence or an insufficiency of time to devote to its furtherance. Lastly, it would appear that not enough attention has always been given to the special needs, and the special limitations, of adult students by those who have been concerned with the teaching of science in extra-mural classes.

To-day it is likely that these last two groups of factors-namely, lack of scientific workers willing to teach in adult education, and lack of attention to the problems of teaching science in adult educationare the most important ones hindering the desired convergence of men of science and laymen in an educational partnership. Students and administrators, alike, are coming more and more to recognize the desirability of such a development, but great difficulty is being found in the provision of suitable tutors. At the present time the teaching of science within the area served by the Cambridge Board of ExtraMural Studies could be at once expanded if more tutors were available, science courses having had to be refused on account of the scarcity of tutors. Men of science who are anxious that their work should not become divorced from the interest and understanding of the ordinary citizen have a responsibility to give this matter their urgent consideration. For the man or woman who has the necessary abilities this work, while often arduous, is most rewarding, not least on account of the extent to which tutors can learn from their students, both in matters of fact and in matters of outlook. Tutors' expenses are found and a fee is paid according to the type of class and the degree of experience of the tutor. Work is normally on a part-time basis, and no more than one class per week need be undertaken. Thus despite the pressure of professional work it should be possible for many more scientific workers to participate in this work than are doing so at present. Persons qualified in some branch of science who would wish to share in the task of bringing the scientific point of view to their fellow citizens should get into touch either with the extra-mural department of the nearest university, or with the central office of the Workers' Educational Association, $38 a$ St. George's Drive, London, S.W.1.

The writer of this article has recently published (Discovery, Sept.-Oct., 1946) a fuller account of techniques found useful in the teaching of science to adults, a review of the problem which it is hoped will 
be of assistance to persons about to undertake work of this kind. Further, there is now an increasing tendency for extra-mural departments of universities to offer some opportunity of training to potential tutors in adult education. For example, in 1947 the Cambridge Board of Extra-Mural Studies will arrange, for the second year in succession, a fortnight's course for this purpose. It will be intended for persons with suitable academic qualifications who need advice about conducting adult classes and teaching their subjects therein. Advice about teaching methods will be given by experienced tutors, and there will be opportunities for meeting and giving practice talks to adult students. Background information concerning adult education and its development will also be given. Such courses do not claim to offer anything in the nature of a complete training, but they provide a valuable opportunity for would-be tutors to acquire some knowledge and personal experience preparatory to embarking upon an adult class.

In a short article it is only possible to consider very generally the part that science has to play in the education of adults, and the form in which it may most readily gain their attention. This is dealt with at greater length in Adult Education.

Experience in the area of the Cambridge Board of Extra-Mural Studies has clearly shown that, at the present time, for the majority of adults interested in adult education it is the approach by way of the social significance of science that is most successful in arousing interest, and in evoking the effort necessary for regular and effective attendance during a course of twelve or more lectures. While the social approach to science is far from being the only important one for the ordinary citizen, it is manifestly the approach of the moment. Scientific workers are accustomed to being opportunists in their own fields, doing what they can, when they can, and how they can. They would do well to employ similar tactics in bringing their subject to the notice of others.

In the hands of a skilful tutor the exposition of science in its social setting can lead to a more informed appreciation of the problems of citizenship, and to a more widespread understanding of the scientific method. Recognition of the fact that science is an activity distinguishable by its methods, rather than the simple pursuit of gadgets and cures, is still very rare among laymen. This situation is largely responsible for the continuance of the belief, still held by many, that science has no place in the liberal education of adults since it has no cultural contribution to make,

The social approach to science makes especial demands upon the tutor, who will need to be widely read outside his own subject, and able to recognize frankly his own vested interest in the scientific outlook. Tendentiousness will bring discredit upon those who practise it as tutors in an educational activity where emphasis is placed upon the need for objective inquiry on the part of students who are motivated by considerations of a practical and social character. To-day the frontiers between natural science on one hand, and psychology, economics, and philosophy on the other, are often vague and difficult of definition. This makes still greater the necessity for objectivity on the part of the tutor. Some men of science will consider it inappropriate to discuss these disputed fields in advance of a more complete study of them by the methods of science. But students will persist in bringing forward wide-ranging issues in which science is involved, such as, for example, the place of scientific method in the investigation of public opinion; the part to be played by science in the formation of opinion, both in propaganda and in education; the attitude of scientific workers to the concepts of creation, free will, democracy, and to the question of the mind-body relationship. Therefore, it would seem advisable that the tutor should be able to deal with such topics in the light of previous contemplation rather than impromptu. Scientific speculation, when self-confessed, can play an important part both in the establishment of new branches of science and in the general advancement of social awareness. It is a characteristic of adult education to be rich in demands for the study of subjects which, at present, do not fall conveniently into the conventional divisions of knowledge made by the universities for their own purposes. This is a fact the implications of which have not yet been very much explored by educationists.

Hitherto the demand for science courses of a more academic character has arisen only from a minority of adults. It is hoped that this demand will develop, both as a result of direct encouragement, and as a result of the more widespread introduction of students to science by way of the social approach. It must, however, be remembered that the intention of adult education is not to produce professional research workers ; though there are a few scholarships enabling exceptionally qualified students to proceed from adult classes to full-time university courses. The hope is, rather, to increase understanding and to widen outlook. Consequently, the teaching methods employed will not necessarily coincide with those suitable for the vocational training of scientific workers. Experience suggests that it is usually better to build up the more academic type of treatment in relation to topies in which there is already some considerable amount of amateur activity. These may be matters of local interest, including natural history; or subjects with vocational aspects, such as gardening, home nursing, motor-car maintenance, or radio. Courses in biology have been very successful when based upon the interests of local field clubs. It is recognized that courses of this type must be as fully experimental as possible-a provision which in adult education still presents many diff. culties from the point of view of organisation.

With respect to both of the routes by which science may be approached, whether social or academic, it is biologists who have made the greatest progress in the business of relating their material to the needs of the ordinary man. It has been said that this has largely resulted from the advantages which biology enjoys with respect to its subject-matter and its methods. With respect to methods, genetics is a department of biology that is to a great extent dependent upon mathematical techniques, and which, like physics and chemistry, is advanced by the use of symbols. Nevertheless, the popularizers of biology have to a considerable extent found it possible to include the subject-matter of genetics within their purview. So far as interest value is concerned, physicists and chemists have acquired a powerful pull on the public mind with the opening of the age of atomic energy. The success of certain carefully designed books expounding the physical sciences for the ordinary man leaves one with the impression that in lecture courses much could be done with similar subject-matter. Indeed, the experience, not only of 
an earlier generation but also of more recent years, is that public interest is keen if lecture courses on such topics are given by lecturers who have the necessary gift of lucid exposition and an ability to relate their subject-matter to the familiar experiences of everyday life. If more physical scientific workers of the present generation would devote time to discovering, by trial and error, techniques suited to the popular exposition of their subjects through the spoken word, these sciences might within a few years come to be as much in demand as the biological sciences.

But experience in adult education suggests that it is not necessary, nor even desirable, for lecturers in science to confine themselves too narrowly within their own research subjects, any more than occurs with school teachers or schools' examiners. Scientific workers when participating in adult education are not authorities addressing their professional equals, but expositors serving the needs of laymen. Their position closely resembles that of the political commentator attempting to assist public understanding of current affairs. Indeed, they may even prove to be more effective as tutors if they can share some of the difficulties experienced by their students when surveying the territory of science. To-day, scientific workers are presented with great opportunities in the field of adult education. Are they willing and ready to take advantage of them?

\section{THE INTERNATIONAL UNION OF PHYSICS}

\section{ACTIVITIES OF THE UNION, 1923-39}

$\mathrm{A}^{2}$ T the close of the First World War, the main pre-war international scientific organisations, some of which had been dominated by Germany, had collapsed. It was therefore decided to create a series of scientific unions to promote international cooperation. The Union of Pure and Applied Physics was formed at the end of 1923 . In 1934 the Union held its most important assembly of the inter-war period. At this assembly, which was held in London, it received a report from the Commission on Standards, Units and Nomenclature which it had previously established. It approved recommendations concerning $(a)$ thermal units, $(b)$ units and nomenclature of electromagnetism (including the adoption of the 'oersted'), and (c) the nomenclature of thermodynamics. It decided that the Commission should continue its work, and should (i) co-operate with other international bodies in relation to definitions of terms, (ii) prepare lists and definitions of terms occurring in two or more branches of physics, and (iii) assist those who, in any country, are preparing such lists. The Commission was not intended to conduct technical investigations, such as those guided by the International Commission on Illumina. tion. It was to receive and to review data prepared by technical commissions and to decide whether to recommend their general adoption by physicists. Associated with the 1934 Assembly was a public conference, including sections on $(a)$ nuclear physics, and $(b)$ the solid state. This very successful conference was held jointly with the Physical Society of London, which was mainly responsible for the organisation.
The work of the International Union of Physics may fairly be compared with that of some of the other unions which are also members of the International Council of Scientific Unions. The International Astronomical Union united thirty-four standing committees and organised many important research projects. The Union of Geodesy and Geophysics was also very active. On the other hand, the projected Union of Biological Sciences never achieved biological existence! The International Union of Pure and Applied Physics was useful-but in a limited way. One reason for its rather slight activity was that its constituent members, the national committees, were not very active in any country, and were non-existent in many.

The Assembly in Paris, January 1947

Against this background we may now consider the recent assembly held at the Sorbonne with Prof. M. Siegbahn (Sweden) as president. The secretary was Prof. P. P. Ewald (Belfast). He had undertaken the office, at the request of the president, after the death of Prof. Abraham, who had been secretary since 1923. The local arrangements were made by Prof. Fleury (director of the Institut d'Optique). The conference recognized that it owed more than a formal vote of thanks to Prof. Ewald and Prof. Fleury, whose hard work in very difficult circumstances enabled it to function smoothly. The following countries were represented: Australia, Belgium, China, Czechoslovakia, Denmark, France, Finland, Great Britain, Italy, Netherlands, Norway, Poland, Spain, Sweden, Switzerland.

From this list it may be seen that Western Europe is well represented, and there were also some scientific workers from Eastern Europe, although the U.S.S.R. did not accept the invitation to attend. It is hoped that the causes which prevented the representation of the United States, Canada and India are purely temporary, and that they will send delegates to the next assembly. It was suggested that ex-enemy States may also be invited as soon as peace treaties have been signed.

Apart from the necessary busin€ss of electing new officers, etc., which will be dealt with later, the chief discussion centred on the future policy of the Union. There were two chief schools of thought. The first view (sponsored by the Dutch delegation) was that the assembly should give a strong lead by appointing a large number of commissions to organise inter. national co-operation in various branches of physics. It was urged that if this were not done, various organisations independent of the International Union of Physics would come into existence. Already a Union of Applied Mechanics and a Union of Crystallo. graphy have been formed. The Réunion des Opticiens held in Paris in October appointed a continuation committee to organise international co-operation in optics. This committee is at present willing to work as part of the International Union of Physics if possible. The Dutch delegates urged the formation of Commissions for Optics, Nuclear Physics, Low Temperatures, Magnetism, Metals, Spectrum Analysis, Cosmic Rays, Crystallography and Mechanics. On the other hand, some delegates felt that an attempt to 'organise physics from above' would certainly fail. Co-operation must be a matter of organic growth. It was believed that all the International Union can do is to recognize an urge for co-operation among a group of workers when it occurs spontaneously (ashad happened with optics) and give the support of the Union. 